\title{
The b-spacing values of white mica from low-grade metapelites of central Nepal Lesser Himalaya and their tectono-metamorphic implications
}

\author{
Lalu P Paudel\# and Kazunori Arita† \\ †Department of Earth and Planetary Sciences, Graduate School of Science, Hokkaido University, Kita 10, Nishi 8, Sapporo \\ 060-0810, JAPAN \\ ‡Permanent address: Central Department of Geology, Tribhuvan University, Kirtipur, Kathmandu, NEPAL \\ * To whom correspondence should be addressed. E-mail: Ialupaude67@yahoo.com, lalu@wlink.com.np
}

\begin{abstract}
Although, enormous P-T data have been constrained from higher-grade rocks of the central Himalayan region (Hodges et al. 1988), P-T data from lower-grade rocks of the Lesser Himalaya are still lacking. In the low-grade metamorphic terrain, the recrystallization of rocks is often not immediately obvious because of the fine-grained character, apparent irregularity in the metamorphism, and only partial recrystallization with preservation of many relict features of the protoliths. Owing to this reason, palaeopressure estimation by thermodynamic calculations is not possible.

White micas are among the most abundant phyllosilicates in low-grade metamorphic rocks. The Tschermak substitution $\left[\left(\mathrm{Mg} \mathrm{Fe}^{2+}\right)^{\mathrm{vi}} \mathrm{Si}^{\mathrm{iv}}=\mathrm{Al}^{\mathrm{vi}} \mathrm{Al}{ }^{\mathrm{iv}}\right]$ between the ideal muscovite and celadoniteend-members, which controls the chemistry of phengites, is thought to be particularly sensitiveto pressureat low-temperature conditions and serves as a qualitative geobarometer (Guidotti and Sassi 1986). Although, the b-spacing values of white micas have been widely used to estimate the palaeopressure in low-grade terrains all over the world, its application in the Himalaya is relatively rare. In the present study, we present the b-spacing values of white mica across Pokhara-Butwal road and Kali Gandaki valley sections of the Lesser Himalaya in central Nepal, and discuss their tectono-metamorphic implications.
\end{abstract}

\section{Geological setting}

The Lesser Himalaya in the Pokhara area is divided into four tectonic units from south to north: Parautochthon with Palpa Klippe lying between the Main Boundary Thrust (MBT) and the Bari Gad-Kali Gandaki Fault (BKF), Thrust Sheet I (TSI) situated between the BKF and the Phalebas Thrust, Thrust Sheet II (TSII) bounded by the Phalebas Thrust and the Lower MCT, and the MCT zone bounded by the Lower MCT and the Upper MCT, respectively. The Lesser Himalaya mostly comprises low-grade metamorphic rocks such as slates, phyllites, quartzites, and dolomites (Nawakot Complex) of the Precambrian age. The Nawakot Complex rocks are unconformably overlain by the Gondwana and postGondwana sedimentary rocks (Tansen Group) in the Parautochthon (Sakai 1983). Metamorphic grade gradually changes from diagenesis to lower anchizone in the Parautochthon to upper anchizone in theTSI, epizone in the TSII and garnet zone in the MCT zone (Paudel 2000).

Sampling and analytical techniques

A total of 320 pelitic rocks with unique assemblage "Mica+Chl+Ab+Qtz" (Chl-zone) and lacking detrital white mica were used to measure $b$-spacing values. A few samples from the northern part of the TS II are from Bt-zone and samples from the MCT zone belong to Grt-zone. M easurement was done on $<2 \mu \mathrm{m}$ powder fraction of each sample.
Diffractometer setting was constant for all the samples (Rigaku Geigerflex diffractometer, Cu cathode, Ni filter, $35 \mathrm{kv}$ tube voltage, $20 \mathrm{~mA}$ current, time constant $=2 \mathrm{sec}$, scatter slit $=1^{\circ}$, receivingslit $=0.3 \mathrm{~mm}$, divergenceslit $\left.=1^{\circ}\right)$. The 63-59. $5^{\circ}$ $2 \theta$ range was scanned at $0.252 \mathrm{è} / \mathrm{min}$, and $\mathrm{b}$ was determined from (060) peak (approx. 61.5 20) using the (211) quartz reflection (approx. $60^{\circ} 2 \theta$ ) as an internal standard. Mean bspacing values were calculated from five repeated measurements for each sample.

Results and implications

The relationship between the b-spacing values with the composition of white mica was accessed by compositional analysis of white mica in the same samples. A fairly good positivelinear correlation was found between the two (Figure 1). This indicates that the b-spacing values serve as indirect measures of phengite content of white mica in the Lesser Himalaya and hence the pressure condition.

The plots of b-spacing values versus the whole rock compositions show no marked correlation indicating that the b-spacing values are sensitive to P-T condition rather than the bulk rock composition. The intensity and shape of the $\mathrm{CuK}_{\alpha 1}$ XRD traces of white mica $(060+331)$ peak gradually change from south (close to the MBT) to north (close to the MCT). Many of the samples from the Tansen Group, Palpa Klippe, Parautochthon, and the TS I show bifurcated or very wide, bluntand asymmetric $(060+331)$ peaks, which are interpreted to be due to the presence of bimodal white mica compositions crystallized at different thermal events (polymetamorphic events, Paudel and Arita 2000).

The b-spacing values vary from $8.970 \AA$ to $9.060 \AA$ in the study area. The average $b$-spacing valuesare relatively smaller in theTansen Group $\left(X_{26}=8.993 \pm 0.033 \AA\right.$ ) compared to those of the Parautochthon $\left(X_{60}^{26}=9.029 \pm 0.01 \AA\right)$ and the Palpa Klippe $\left(X_{20}=9.039 \pm 0.005 \AA\right)$. Average $b$-spacing values from the TS I $\left(X_{109}=9.041 \pm 0.011 \AA\right)$ are also similar to those of the Parautocthon and the Palpa Klippe. The b-spacingvalues sharply drop across the Phalebas Thrust. The average bspacing values for the TS II and the MCt zone are $\left(X_{82}=9.016 \pm 0.012 \AA\right)$ and $\left(X_{20}=9.001 \pm 0.011 \AA\right)$, respectively.

The b-spacing value increase with depth to the south of the PhalebasThrust, i.e., higher values for older units. It shows that the rocks attained peak pressure when they were at normal stratigraphic position. Therefore, older units experienced higher pressure due to thicker overload. However, it is interesting to note that the trend of b-spacing values is reversed to the north of the PhalebasThrust, i.e., lower values for older units. It is argued that the decrease in b-spacing values is the result of thermal dephengitization of the white mica dueto higher temperature condition in thenorthern part of the Lesser Himalaya. 
A cumulative frequency plot of the total data of each tectonic unit from the present area (Figure 2) shows that the TS I, Parautochthon, and the Palpa Klippe have b-spacing values comparable to those of the Eastern Alps and Otago metamorphic belts suggesting a typical Barrovian-type (intermediate-P) metamorphism. On the other hand the MCT zone, TSII and theTansen Group have b-spacingvaluessimilar to that of the Bosost, N. New Hampshire and Ryoke metamorphic belts. TheTansen Group occupies theshallowest position in the stratigraphic sequence. Therefore, thelower bspacing values from the Tansen Group are likely due to low-P metamorphic condition.

Using the P-T-b grid of Guidotti and Sassi (1986), the approximatepalaeopressures have been estimated to be about 4 kbars for the TSII , TSI and Parautochthon. The estimated pressures give approximate burial depths of $15 \mathrm{~km}$ assuming an average bulk density of $2.60 \mathrm{gm} \mathrm{cm}^{-3}$ for the metasediments. Thus, the estimate of the average background geothermal gradient at the time of peak metamorphism would be $27^{\circ} \mathrm{C} /$ $\mathrm{km}$ for theTSII (using peak $\mathrm{T}=400^{\circ} \mathrm{C}$ given by illite crystallinity; Paudel 2000), $22^{\circ} \mathrm{C} / \mathrm{km}$ for the rest of the area to the south of the Phalebas Thrust (using peak $\mathrm{T}=325^{\circ} \mathrm{C}$ given by IC).

TheP-T structure for the Neohimalayan metamorphism revealed from b-spacing values can be explained in relation to the thrust tectonics, i. e., overthrusting of the hot Higher Himalayan rocks over the cold Lesser Himalayan (LeFort 1975 Arita 1983). Lower geothermal gradient and lesser thickness of overburden during peak metamorphism in the southern

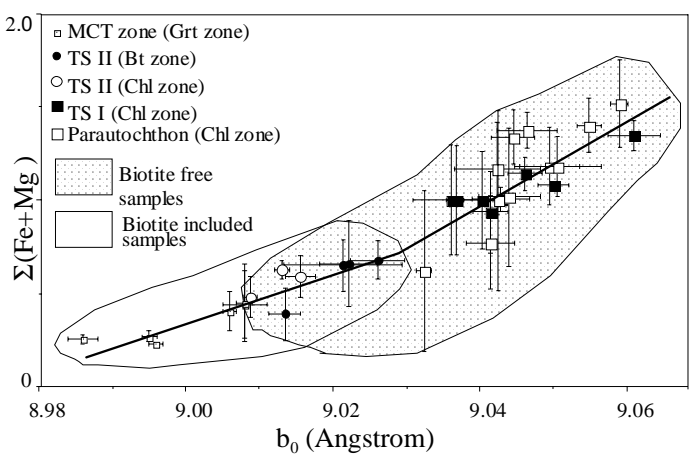

FIGURE 1. Plots of phengite content $(\mathrm{Fe}+\mathrm{Mg})$ versus the $\mathrm{b}$-spacing values of white micas from the Tansen-Pokhara section. The two show good correlation $(r=7.2)$ in the area part (frontal part of the orogen) of the Lesser Himalaya may be the reflection of cool and thin leading edge of the MCT.

\section{References}

Arita K.1983. Origin of the inverted metamorphism of the Lower Himalayas, central Nepal. Tectonophysics 95: 43-60

Guidotti CV and FP Sassi. 1986. Classification and correlation of metamorphic facies series by means of muscovite $b$ data from lowgrade metapelites. Neues Jahrb Mineral Abhand 153: 363-380

Hodges KV, MS Hubbard and DS Silverberg. 1988. Metamorphic constraints on the thermal evolution of the central Himalayan orogen. Philosophical Trans Royal Soc London A326: 257-280

Le Fort P. 1975. Himalaya: the collided range. Present knowledge of the continental arc. Am J Sci 275A: 1-44

Paudel LP and K Arita. 2000. Tectonic and polymetamorphic history of the Lesser Himalaya in central Nepal. J Asian Earth Sci 18: 561-584

Paudel LP. 2000. Geological and petrological studies of the central Nepal Himalaya with special reference to tectono-thermal evolution and inverted metamorphism in the Lesser Himalaya. PhD Dissertation (submitted to the Hokkaido Univertisy, Japan), $155 \mathrm{p}$

Sakai H. 1983. Geology of the Tansen Group of the Lesser Himalaya in Nepal: Memoirs of the Faculty of Science, Kyushu University, Series D, Geology 25: 27-74.

Sassi FP and A Scolari. 1974. The b value of the potassic white micas as a barometric indicator in low-grade metamorphism of pelitic schists. Contrib Mineral Petrol 45: 143-152

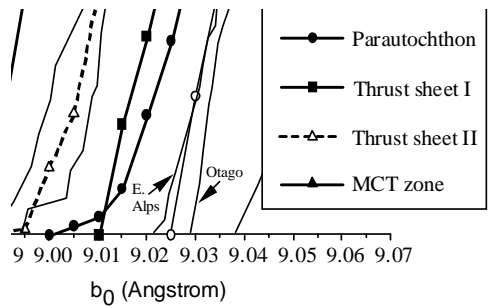

FIGURE 2. Cumulative frequency curves of $b$-spacing values for different tectonic units in the Lesser Himalaya. Cumulative frequency curves for the other orogenic belts are after Sassi and Scolari (1974) 